Nig. J. Biotech. Vol. 36 (2) : 114-126 (Dec 2019)

ISSN: 01891731

Available online at

NIGERIAN JOURNAL OF

BIOTECHNOLOGY

http://www.ajol.info/index.php/njb/index

and www.biotechsocietynigeria.org

DOI: https://dx.doi.org/10.4314/njb.v36i2.12

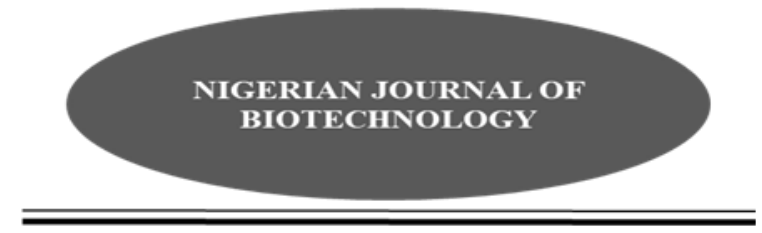

\title{
Production, purification, and characterization of a-amylase from Aspergillus niger, Aspergillus flavus and Penicillium expansum using cassava peels as substrate
}

\author{
Aisien, E. T. and Igbinosa, I. H. \\ Department of Environmental Management and Toxicology, Faculty of Life Sciences, \\ University of Benin, Benin city.
}

\begin{abstract}
Cassava peels are waste generated from cassava processing and are mostly disposed of in Nigeria by dumping indiscriminately in landfills/waste dumps where they remain as huge mounds and constitute nuisance to the environment. This study was carried out using cassava peels as substrate for the production of a - amylase from three fungi (Aspergillus flavus, Aspergillus niger and Penicillium expansum) selected from twelve microbial isolates obtained from biodegrading cassava peels. The fungi were isolated using cassava peel agar medium and the $a-$ amylase was produced by the solid state fermentation process. The $a-$ amylase was assayed by measuring the decrease in staining power of starch with iodine reagent at $620 \mathrm{~nm}$ and purified by using Sephadex G-100 and Sephadex C-50. The a amylase was characterized by examining the effect of temperature, stability at $70^{\circ} \mathrm{C}, \mathrm{pH}$, substrate concentration, metal ions and EDTA. The results show that the purification fold and specific activity were $95.727,1.053$ Units/mg protein; 81.830, 0.982 Units/mg protein and 85.784, 0.686 Units/mg protein for $A$. flavus, $A$, niger and $P$. expansum respectively. The optimum temperature and $\mathrm{pH}$ were $45^{\circ} \mathrm{C}$ and 4.5 respectively. It was observed that the a amylase still retained some activity after heating at $70^{\circ} \mathrm{C}$ for $35 \mathrm{~min}$. The a - amylase activity increased with increase in substrate concentration and metal ion concentration $\left(\mathrm{Na}^{+}, \mathrm{K}^{+}\right.$, $\mathrm{Mg}^{2+}$ and $\mathrm{Ca}^{2+}$ ) but decreased with increase in heavy metal ion concentration ( $\mathrm{Hg}^{2+}$ and $\mathbf{P b}^{2+}$ ) and EDTA.
\end{abstract}

Key words: Cassava peels, a - amylase, fungi, starch and Sephadex C -50 . Corresponding author: eki.aisien@uniben.edu. Tel: +234(0)8027364660

\section{Introduction}

Cassava (Manihot esculenta Crantz) is one of the most popular and widely consumed food crop in Nigeria; it is a cornerstone of food security. Nigeria is the world largest producer of cassava (Kayode, 2016). Cassava processing produces large amounts of waste of which the peels constitute a large proportion. Approximately 98 percent of Nigeria's cassava peels annually are wasted due to the constraints associated with drying and the concerns about safety of its use, particularly the hydrocyanide and mycotoxins related food poisoning (ILRI news, 2015). Cassava peels are perishable and are mostly disposed of by dumping indiscriminately in landfill/waste dumps where they remain as huge mounds and constitute nuisance to the environment (Aisien and Ikenebomeh, 2017). Cassava peels are made up of $9.65 \%$ starch (Aisien and Ikenebomeh, 2017). Starch is a polymer of glucose linked by the glycosidic bond, amylose and amylopectin are the two types of glucose polymers present in starch. Amylose is a linear polymer consisting of up to 6000 glucose units with a-1,4 glycosidic bonds, while amylopectin consists of short a-1,4 linked to linear chains of $10-60$ glucose units and $a-1,6$ linked to side chains with 15 to 45 
glucose units (de Souza and eMagalhaes, 2010). Amylose constitutes $20-25 \%$ of the starch molecule and the remaining $75-80 \%$ of the starch molecule is amylopectin (Sundarram and Murthy, 2014).

Amylases are important hydrolase enzymes which randomly cleave internal glycosidic linkages in starch molecules and hydrolyze them to yield dextrins and oligosaccharides (Sundarran and Murthy, 2014). The amylase enzymes are of three different types which are the $a$ - amylase, $\beta$ - amylase and $Y$ - amylase (Sivaramakrishnan et al., 2006).

a - amylase (a - 1, 4 - glucan - 4 glucanohydrolase) catalyses the initial hydrolysis of starch into shorter oligosaccharides through the cleavage of $a-D-(1-4)$ glycosidic bonds (Tangphatsornruang et al., 2005). It neither cleaves the terminal glucose residues nor $a-1$, 6 - linkages. The end products of a - amylase action are oligosaccharides with varying length of $a-$ configuration and $a-$ limit dextrins which constitute a mixture of maltose, maltotriose and branched oligosaccharides of $6-8$ glucose units that contain both $a-1,4$ and $a-1,6$ linkages (Whitcomb and Lowe, 2007). In the past, starch was hydrolyzed into glucose by acid hydrolysis, the operating conditions were high acidic concentration and high temperature. These limitations have been overcome by the use of a - amylase. a - amylase have replaced acid hydrolysis in over $75 \%$ of starch hydrolyzing processes (Rajunathan and Padhmadas, 2013). a - amylase has wide applications in the brewing, detergent and food industries (Mukesh et al., 2012), textile, clinical, medical, analytical chemistry and pharmaceutical industries, (Gupta et al., 2003).

a - amylase can be sourced from plants, animals and microbes (Oboh, 2005, Bole et al., 2013, Erdal et al., 2010). The microbial source of a - amylase is preferred to other sources because of its plasticity and vast availability (Shivaji et al., 2013). a - amylase is produced by several bacterial, fungi and genetically modified species of microbes (Sundarram and Murthy, 2014). The Bacillus $\mathrm{sp}$ is the most widely used source among the bacterial species while among the fungal sources the Aspergillus species are mostly used with only few species of Penicillium. a - amylases are produced by the solid state fermentation (SSF) and submerge fermentation (SMF) processes (Couto and
Sanroman, 2006, Kunamneni et al.,2005). The solid state fermentation process has gained huge interest in recent years due to advantages like yield and high specificity, simple technique, low moisture contents, which prevent bacterial contamination, low capital investment, lower levels of catabolite repression, and better product recovery (Couto and Sanroman, 2006). The SSF is also advantageous in that it uses nutrient rich waste materials which can be easily recycled as substrates (Kunamneni et al., 2005). Sodhi et al (2005) produced a - amylase from Bacillus sp using wheat bran, rice bran and corn bran, hence the objective of this study is to produce a - amylase from fungi sources using cassava peels as substrates.

\section{Materials and Methods}

\section{Isolation of cassava peel degrading fungi}

Sterile cassava peel agar medium (CPAM) was used for the isolation of cassava peel degrading fungi. CPAM was prepared by the addition of 15 $\mathrm{g}$ of Agar to $1000 \mathrm{ml}$ of cassava peel extract and sterilized at $120^{\circ} \mathrm{C}$ for 15 min. Cassava peel extract was prepared by adding $50 \mathrm{~g}$ of ground fresh cassava peels to $1000 \mathrm{ml}$ of distilled water and then filtered through cheese cloth. Serial dilution of $10^{-7}$ of decomposing cassava peels were used to prepare three plates and incubated aerobically at $28 \pm 02^{\circ} \mathrm{C}$ for 72 hours. The fungal isolates were sub cultured into sterile malt extract agar plates and further sub cultured into the other sterile malt extract agar plates to obtain pure cultures.

Characterization and identification of fungal isolates

The fungi isolates grown on sterile malt extract agar were identified based on cultural and morphological characteristics using standard fungi identification methods outlined by Barnett and Hunter (1972), Pitt (1979) and Gilman (2001).

\section{Establishment of biodegradability}

Fresh cassava peels were washed under running tap water and surface sterilized in $10 \% \mathrm{v} / \mathrm{v}$ sodium hypochlorite for $1 \mathrm{hr}$. (Ikediugwu and Ejale, 1980). The cassava peels in separate sterile petri dish was each inoculated with a 4 day old fungi culture and incubated at $28 \pm 2^{\circ} \mathrm{C}$ for 7 days. The rate of biodegradability was then examined by measuring the areas degraded by each isolate. This was done in triplicates. Selection of fungal species for extracellular a- 
amylase production was done based on the rate of zone of clearance around the colony.

Preparation of inoculums and solid state fermentation

Seventy -two hrs old cultures were used in the preparation of the inoculums, from which a spore suspension with a spore load of approximately $6 \times 10^{4}$ spores per $\mathrm{ml}$ was made.

Apparently healthy freshly harvested cassava tubers were washed and peeled. The peels were further washed with tap water. A cork borer was used to make cores of cassava peels of $3 \mathrm{~mm}$ thickness to expose more surface area for fungal attack. The cassava peel discs were surface sterilized in $3 \% \mathrm{w} / \mathrm{v}$ sodium hypochlorite solution for one hr. The cassava peel discs were afterwards rinsed with six changes of sterile distilled water to remove the residual effect of the sodium hypochlorite. Twenty grams of cassava peel discs were weighed out and transferred into $250 \mathrm{ml}$ Erlenmeyer flasks containing $10 \mathrm{ml}$ of sterile distilled water for solid state fermentation. Each flask was inoculated with $1 \mathrm{ml}$ of the spore suspension and incubated at $28^{\circ} \mathrm{C} \pm 2^{\circ} \mathrm{C}$ for 8 days. The experimental set ups were examined daily for fungal growth and degradation of the cassava peel discs.

Assay for a-amylase.

Two grams of cassava peels from the inoculated flasks were homogenized with $30 \mathrm{ml}$ of $2 \mathrm{mM}$ sodium acetate buffer $\mathrm{pH} 6.8$ for $10 \mathrm{~min}$. The homogenate was centrifuged at $6000 \times \mathrm{g}$ for 15 min, the supernatant fraction was then incubated for $15 \mathrm{~min}$ at $70^{\circ} \mathrm{C}$ to inactivate $\beta$ amylase. Thereafter, it was cooled to $28 \pm 2^{\circ} \mathrm{C}$ and used for the assay of a-amylase according to the method of Bidderback (1971) by measuring the decrease in staining power of starch with iodine reagent at $620 \mathrm{~nm}$. a-Amylase activity was expressed as decrease in absorbance $\min ^{-1} \mathrm{ml}^{-1}$ of liquor extract. The reaction mixture contained $2.0 \mathrm{ml}$ of saturated starch solution in a test tube and $1.0 \mathrm{ml}$ of crude enzyme. A starch blank was set up with $2.0 \mathrm{ml}$ of saturated starch solution and $1.0 \mathrm{ml}$ of boiled enzyme. The tubes were incubated at $37^{\circ} \mathrm{C}$ for $10 \mathrm{~min}$. and reaction was then stopped by the addition of $1.0 \mathrm{ml}$ of iodine reagent. Absorbance was read at $620 \mathrm{~nm}$ using a spectrophotometer against a blank containing $3.0 \mathrm{ml}$ of distilled water and $1.0 \mathrm{ml}$ of iodine reagent. a-amylase activity was expressed as decrease in absorbance in minute/ml of liquor extract.

\section{Enzyme extraction}

Fungal growth in the incubated flasks were noticed at about 48 hours of incubation after which daily analysis for the detection of a amylase activity commenced. Three flasks, each of Aspergillus niger, Aspergillus flavus, and Penicillium expansum were analyzed daily. The cassava peel discs in each flask were chilled for $20 \mathrm{~min}$ and homogenized with cooled liquid extract solution $(1: 1 \mathrm{w} / \mathrm{v})$. The extract solution consists of $0.5 \mathrm{M} \mathrm{NaCl}$ containing $5 \mathrm{mM}$ of $\mathrm{NaN}_{3}$ to prevent microbial contamination. The homogenate from each flask was clarified by passing it through glass fiber filter (Whatman Gf/A). Each filtrate was analyzed for a-Amylase. The $\mathrm{pH}$ and the protein content of filtrate (crude enzyme) were determined. After the peak of enzyme production was reached few daily analyses were still carried out to confirm the established peak.

\section{Purification of a-Amylase}

Ammonium sulphate precipitation

The crude enzyme was precipitated with $90 \%$ ammonium sulphate solution at $4^{\circ} \mathrm{C}$ for $24 \mathrm{hrs}$. The resulting precipitate was collected by centrifugation at $20,000 \times \mathrm{g}$ for $30 \mathrm{~min}$. The precipitate was dissolved in $10 \mathrm{ml}$ of citrate phosphate buffer ( $\mathrm{pH} \mathrm{6.0)}$ and dialyzed against two changes of the same buffer for $24 \mathrm{hrs}$. The protein content of the enzyme was determined by the method of Lowry et al., (1951) sited in Biancarosa et al., (2017).

Further purification using Sephadex G-100 and Sephadex C- 50

The dialyzed enzyme concentrate $(10 \mathrm{ml})$ was applied to the Sephadex G-100 column and eluted

with $0.05 \mathrm{M}$ citrate phosphate buffer containing $5 \mathrm{mM}$ of $\mathrm{NaN}_{3}$ as described by Olutiola and Ayres (1973). Three fractions (5 ml per tube) were collected and the protein content in each was determined by the method of Lowry et al., (1951). These fractions were further analyzed for enzyme activities. The fraction of the enzyme which showed highest enzyme activity after gel filtration were concentrated in a rotary evaporator (Buchi Rota Vapor R) at $28 \pm 2^{\circ} \mathrm{C}$. The enzyme concentration was made up to $10 \mathrm{ml}$ by adding $0.2 \mathrm{M}$ citrate phosphate buffer ( $\mathrm{pH} 6.0$ ) and applied to the column of Sephadex C - 50 . This was then eluted with the same buffer containing $0.2 \mathrm{MKCL}$. Fractions of $5 \mathrm{ml}$ per tube, were collected and their protein content 
measured. The enzyme activity was also determined.

\section{Characterization of the purified enzyme}

The effect of some physiochemical parameters on the activities of the purified (SP C - 50 fraction) enzyme was examined.

Optimum temperature determination

In order to determine the optimum temperature for a-Amylase activity of the purified enzyme, the reaction mixture was incubated at 5, 10, 15, $20,25,30,35,40,45$ and $50^{\circ} \mathrm{C}$ for 3hrs. Enzyme activity was determined after incubation for each of the above temperature.

Effect of heating at $70^{\circ} \mathrm{C}$

The effect of heat on the stability of the enzyme was determined. Samples of the purified enzyme were heated at $70^{\circ} \mathrm{C}$ for different periods of time $(0,5,10,15,20,25,30$ and 35min respectively). The activity of the heated enzyme was measured by incubating the enzyme substrate mixture at $35^{\circ} \mathrm{C}$ for $3 \mathrm{hrs}$.

\section{Optimum $\mathrm{pH}$ determination}

Optimum $\mathrm{pH}$ was determined by preparing substrates with $\mathrm{pH}$ ranging from 3.0 to 9.0 citrate

phosphate buffer $(0.02 \mathrm{M})$ was used to prepare substrate of $\mathrm{pH} 3.0,3.5,4.0,4.5,5.0,5.5,6.0$, 6.5 and 7.0 whereas $0.2 \mathrm{M}$ Tris-HCL buffer was used to prepare substrates of pH.7.5, 8.0, 8.5 and 9.0 starch $(10 \%)$ of $\mathrm{pH}$ ranging between 3.0 and 7.0 were employed as substrate for the enzyme assay. The $\mathrm{pH}$ of the substrate was adjusted where necessary with $0.1 \mathrm{M} \mathrm{HCL}$ and $0.01 \mathrm{M} \mathrm{NaOH}$.

Effect of substrate concentration

In order to determine the concentration of the substrate at which enzyme activity will be highest, the substrate concentration was varied between $2 \mathrm{mg} / \mathrm{ml}-18 \mathrm{mg} / \mathrm{ml}$.

\section{Determination of the effect of metal ions}

The effect of some metal ions at various concentrations on the activity of the enzyme was determined. The substrate was incubated with each test metal ion at $4^{\circ} \mathrm{C}$ for $3 \mathrm{hrs}$ respectively before being employed in enzyme assays. Different concentration $(5-40 \mathrm{mg} / \mathrm{ml})$ of $\mathrm{Na}^{+}, \mathrm{K}^{+} \mathrm{Ca}^{2+}$ and $\mathrm{Mg}^{2+}$ (sodium chloride, potassium chloride, calcium chloride and magnesium chloride) ions were employed for the investigation. Concentrations of 1 to 10 $\mathrm{mg} / \mathrm{ml}$ were employed for $\mathrm{Hg}^{2+}$ and $\mathrm{pb}^{2+}$ (mercury II chloride and lead II chloride) ions.

Effect of Ethylene diamine tetra acetic acid

The effect of ethylene diamine tetra acetic acid at concentrations of 1 to $10 \mathrm{mg} / \mathrm{ml}$ on the activity of the enzyme was determined. The substrate was incubated initially with ethylene diamine tetra acetic acid at $4^{\circ} \mathrm{C}$ for 3 hrs before they were employed in enzyme assay. All the analysis was performed in triplicate. The mean value was taken as the result.

\section{Results and discussion}

The following twelve fungi shown in Table 1 were isolated from cassava peels undergoing biodegradation, they were identified based on their cultural and morphological characteristics. They were found to be capable of degrading cassava peels. The order of degradability is Aspergillus flavus, > Aspergillus niger > Penicillium expansum > Aspergillus tamarri > Penicillium frequentants $>$ Penicillium. crustaceum > Geotrichum candidum > Fusarium oxysporum > Rhizopus oryzae > Trichoderma viride > Mucor hiemalis > Saccharomyces cerevisiae as shown in Table 1.

Table 1: Biodegradability of cassava peels

\begin{tabular}{|ll|}
\hline Fungi & Degraded distance (mm) \\
\hline Aspergillus flavus & $45.10 \pm 2.4$ \\
Aspergillus niger & $42.70 \pm 3.2$ \\
Penicillium expansum & $37.10 \pm 5.0$ \\
Aspergillus tamari & $33.30 \pm 2.8$ \\
Penicillium frequentans & $26.60 \pm 1.9$ \\
\hline
\end{tabular}




\begin{tabular}{|ll|}
\hline Penicillium crustaceum & $24.40 \pm 3.6$ \\
Geotrichum candidum & $19.80 \pm 2.0$ \\
Fusarium oxysporum & $18.00 \pm 1.7$ \\
Rhizopus oryzae & $15.20 \pm 3.5$ \\
Trichderma viride & $15.00 \pm 2.1$ \\
Mucor hiemalis & $12.90 \pm 1.5$ \\
Saccharomyces cerevisiae & $12.88 \pm 1.5$ \\
\hline
\end{tabular}

Results are means \pm standard deviations of three determinations per microbial isolate.

Three fungi (Aspergillus flavus, Aspergillus niger and Penicillium expansum) with the highest degraded distance (Table 1) were selected for enzyme studies. These resulted agreed with that of Adeniran and Abiose (2009) who reported that $A$. flavus showed greater potential in the production of a-amylase among the other isolates they tested on agricultural waste.

The crude enzyme produced by the selected fungi inoculated cassava peels exhibited a amylase

activities. The peak of a-amylase production was recorded at day 4 , and this with the associated total protein and $\mathrm{pH}$ are presented in Table 2

The a-amylase activity in the crude enzyme from cassava peels inoculated with Aspergillus flavus, Aspergillus niger and Penicillium expansum were 0.097 units, 0.088 units and 0.058 units respectively (Table 2 ). This shows that the aamylase activity increased in the order $A$. flavus $>A$. niger $>P$ expansum. This order was also maintained after the purification process. The a -amylase activity after purification was a function of the purification process.

The a-amylase activity for the ammonium sulphate purification process was lower than that of the crude along with the total protein and percentage yield but the specific activity and purification fold were higher, for $A$. flavus, they were 0.082 units, $1.206 \mathrm{mg}, 84.536 \%$, 0.068 units/mg protein and 6.181 (Table 3), for A. niger, they were 0.073 units, $1.203 \mathrm{mg}$, $82.955 \%, 0.066$ units $/ \mathrm{mg}$ protein and 5.500 (Table 4) and that for $P$. expansum were 0.049 units, $0.975 \mathrm{mg}, 84.453 \%, 0.050$ units $/ \mathrm{mg}$ protein and 6.282 respectively (Table 5 ). The aamylase activity for the Sephadex G-100 purification process were also lower than that of the ammonium sulphate purification process along with the total protein and percentage yield while the specific activity and purification fold were higher, for $A$. flavus, they were 0.070 units, $0.214 \mathrm{mg}, 72.165 \%, 0327$ units $/ \mathrm{mg}$ protein and 29.737 (Table 3), for $A$. niger, they were 0.062 units, $0.190 \mathrm{mg}, 70.455 \%, 0.326$ units/mg protein and 27.170 (Table 4) and that for the $P$. expansum were 0.041 units, 0.165 $\mathrm{mg}, 70.690 \%, 0.249$ units $/ \mathrm{mg}$ protein and 31.061 (Table 5). The a-amylase activity for the Sephadex C-50 purification process also followed the same pattern for Sephadex G-100 purification process (Tables 3,4 \&5).

Table 2: a-Amylase activity, total protein and pH at the peak of enzyme production

\begin{tabular}{|c|c|c|c|}
\hline Fungus & $\begin{array}{l}\text { Total a-Amylase } \\
\text { activity (units) }\end{array}$ & Total protein $(\mathbf{m g})$ & pH \\
\hline Aspergillus flavus & 0.097 & 8.68 & 4.5 \\
\hline Aspergillus niger & 0.088 & 7.280 & 4.5 \\
\hline
\end{tabular}




\begin{tabular}{|llll|}
\hline Penicillium expansum & 0.058 & 6.990 & 4.5 \\
\hline
\end{tabular}

The purification profiles for the production of a-amylase from Aspergillus flavus, Aspergillus niger and Penicillium expansum are presented in Tables 3-5.

Table 3: Purification profile of a-amylase obtained from cassava peels degraded by Aspergillus flavus

\begin{tabular}{|lllllll|}
\hline Fraction & $\begin{array}{l}\text { Total } \\
\text { Amylase } \\
\text { activity (units) }\end{array}$ & $\begin{array}{l}\text { a- } \\
\text { protein } \\
\text { (mg) }\end{array}$ & $\begin{array}{l}\text { Specific activity } \\
\text { (unit/mg } \\
\text { protein) }\end{array}$ & $\begin{array}{l}\text { Yield } \\
\text { \% }\end{array}$ & $\begin{array}{l}\text { Purification } \\
\text { fold }\end{array}$ \\
\hline Crude & 0.097 & 8.680 & 0.011 & 100.000 & 1.000 \\
$\left(\mathrm{NH}_{4}\right)_{2} \mathrm{SO}_{4}$ & 0.082 & 1.206 & 0.068 & 84.536 & 6.181 \\
$\mathrm{G}-100$ & 0.070 & 0.214 & 0.327 & 72.165 & 29.737 \\
$\mathrm{SP} \mathrm{C}-50$ & 0.060 & 0.057 & 1.053 & 61.856 & 95.727 \\
\hline
\end{tabular}

Table 4: Purification profile of a-amylase obtained from cassava peels degraded by Aspergillus niger

\begin{tabular}{|llllll|}
\hline Fraction & $\begin{array}{l}\text { Total } \\
\text { Amylase } \\
\text { activity (units) }\end{array}$ & $\begin{array}{l}\text { a- } \\
\text { protein } \\
(\mathbf{m g})\end{array}$ & $\begin{array}{l}\text { Specific activity } \\
\text { (unit/mg } \\
\text { protein) }\end{array}$ & $\begin{array}{l}\text { Yield } \\
\%\end{array}$ & $\begin{array}{l}\text { Purification } \\
\text { fold }\end{array}$ \\
\hline Crude & 0.088 & 7.280 & 0.012 & 100.000 & 1.000 \\
$\left(\mathrm{NH}_{4}\right)_{2} \mathrm{SO}_{4}$ & 0.073 & 1.203 & 0.066 & 82.955 & 5.500 \\
$\mathrm{G}-100$ & 0.062 & 0.190 & 0.326 & 70.455 & 27.170 \\
$\mathrm{SP} \mathrm{C}-50$ & 0.053 & 0.054 & 0.982 & 60.227 & 81.830 \\
& & & & & \\
\hline
\end{tabular}

Table 5: Purification profile of a-amylase obtained from cassava peels degraded by Penicillium expansum

\begin{tabular}{|lllllll|}
\hline Fraction & $\begin{array}{l}\text { Total } \\
\text { Amylase } \\
\text { activity (units) }\end{array}$ & $\begin{array}{l}\text { Total } \\
\text { protein } \\
\text { (mg) }\end{array}$ & $\begin{array}{l}\text { Specific activity } \\
\text { (unit/mg } \\
\text { protein) }\end{array}$ & Yield \% & $\begin{array}{l}\text { Purification } \\
\text { fold }\end{array}$ \\
\hline Crude & 0.058 & 0.990 & 0.008 & 100.000 & 1.000 \\
$\left(\mathrm{NH}_{4}\right)_{2} \mathrm{SO}_{4}$ & 0.049 & 0.975 & 0.050 & 84.453 & 6.282 \\
$\mathrm{G}-100$ & 0.041 & 0.165 & 0.249 & 70.690 & 31.061 \\
\hline
\end{tabular}




\begin{tabular}{llllll}
\hline SP C -50 & 0.035 & 0.051 & 0.686 & 60.345 & 85.784
\end{tabular}

Varalakshim et al., (2009) reported higher aamylase activity for $A$. niger. Similarly, Shivakumar et al., (2012) also reported higher a-amylase activities and higher values of specific activities for the Aspergillus and Penicillium species.

The effect of temperature on a-amylase activity is shown in Figure 1. The optimum temperature obtained for the a-amylase produced by the above fungi were found to be $45^{\circ} \mathrm{C}$. The temperature optima obtained in this study is similar to that reported by Sundarram and Murthy (2014) for a-amylase production by $B$. Licheniformis. Prakasham et al. (2006) also reported an optimum temperature of $45^{\circ} \mathrm{C}$ for Penicillium janthinelum while Thippeswany et al. (2006) reported a temperature optimum of $50^{\circ} \mathrm{C}$

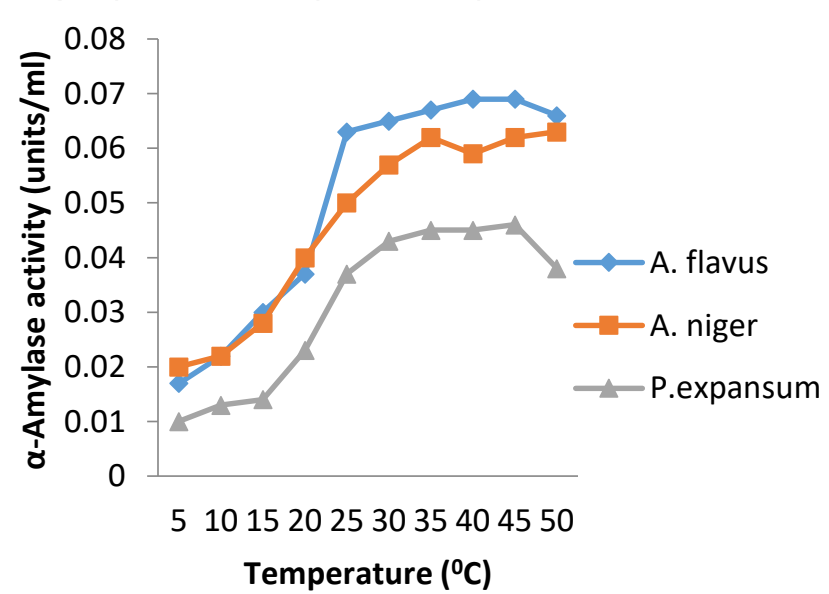

Fig. 1: Effect of temperature $\left({ }^{\circ} \mathrm{C}\right)$ on the

activity of purified $\alpha$-amylase from

cassava peels

The effect of $\mathrm{pH}$ on the activity of a-amylase is shown in Figures 3. The activity of the aamylase from $A$. flavus increased from 0.030 units $/ \mathrm{ml}$ at a $\mathrm{pH}$ of 3.5 to 0.059 units/l at pH 4.5 and thereafter decreased to 0.018 units $/ \mathrm{ml}$ at $\mathrm{pH}$ 7.5. There were similar increases before decreases in a-amylase activity for $A$. niger (increase from 0.035 units $/ \mathrm{ml}$ at a pH of 3.5 to 0.057 units $/ \mathrm{ml}$ at $\mathrm{PH} 4.5$ and decreased to 0.019 unit/ml at $\mathrm{pH} .7 .5$ ) and $P$. expansum (increased from 0.020 units $/ \mathrm{ml}$ at $\mathrm{pH} .3 .5$ to 0.034 units $/ \mathrm{ml}$ at $\mathrm{pH} 4.5$ and decreased to 0.008 units $/ \mathrm{ml}$ at $\mathrm{pH}$. 7.5). The results indicate that the optimum $\mathrm{pH}$ for a-amylase activity from the above fungi was 4.5. This result differs from those of de for Aspergillus oryzae. In this study it was observed that the a-amylase activity for the fungi examined increased from $5^{\circ} \mathrm{C}$ to $45^{\circ} \mathrm{C}$ after which there was a decline in activity when temperature was increased.

The stability at $70^{\circ} \mathrm{C}$ of a-amylase produced in this study is shown in Figure 2. It was observed that there was a gradual decrease in the activity of the a-amylase with $P$. expansum recording the highest level of decrease. This was followed by $A$. niger before $A$. flavus. The order of decrease was $P$. expansum $>A$. niger $>A$. flavus. This result is in agreement with that reported by Bole et al. (2013), where there were decrease in the a-amylase activity of a Bacillus $s p$ when temperature was increased from $10^{\circ} \mathrm{C}$ to $60^{\circ} \mathrm{C}$.

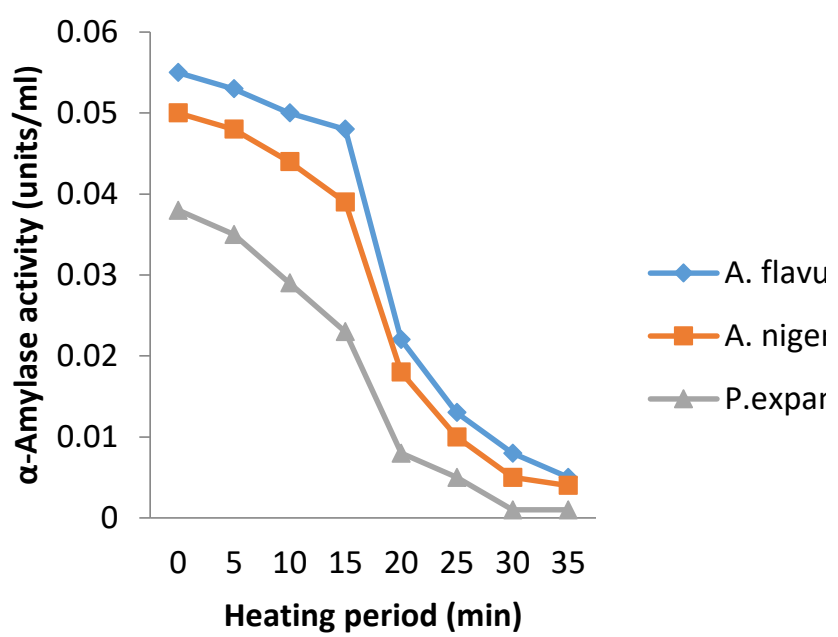

Fig. 2: Effect of heating $\left(70^{\circ} \mathrm{C}\right)$ on the activity of purified $\alpha$-amylase from cassava peels Souza and eMagalhaes (2010), where a pH optimum of 4.95 was reported for Aspergillus niger and an optimum pH of 6.0 for Aspergillus oryzae.

The effect of substrate concentration on the activity of a-amylase is shown in Figure 4. The activity of the a-amylase from $A$. flavus increased from 0.020 units $/ \mathrm{ml}$ to 0.085 unit $/ \mathrm{ml}$ as the substrate concentration increased from 2 $\mathrm{mg} / \mathrm{ml}$ to $14 \mathrm{mg} / \mathrm{ml}$. Further increase in substrate concentration from $14 \mathrm{mg} / \mathrm{ml}$ to 18 $\mathrm{mg} / \mathrm{ml}$ resulted in no increase in the a-amylase activity. Similar trends were observed for $A$. niger and $P$. expansum. The order of increase in a-amylase activity with increase in substrate 
concentration is $A$. flavus $>A$. niger and $P$. expansum. This result agrees with the report of Aisien and Ikenebomeh (2017), that increase in substrate concentration leads to increase in enzyme activity until a point whereby further increase in substrate concentration will no longer lead to increase in enzyme activity.

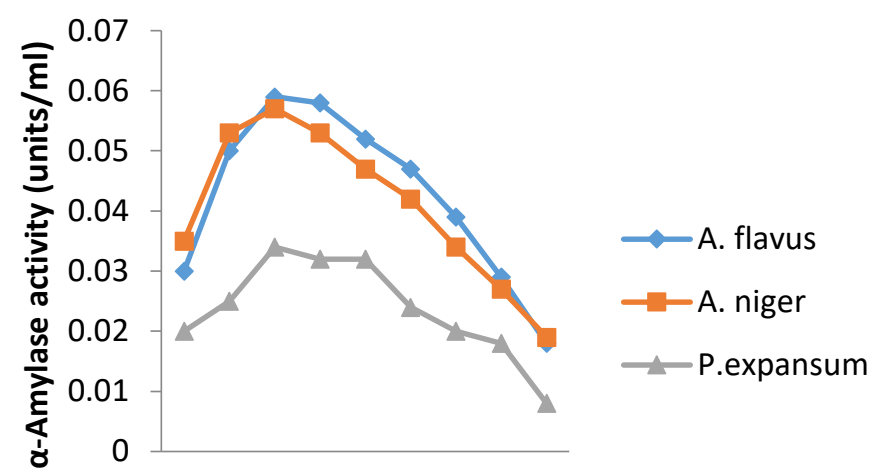

3.544 .555 .566 .577 .5

$\mathrm{pH}$

Fig. 3: Effect of $\mathrm{pH}$ on the activity of purified $\alpha$-amylase from cassava peels
Similar explanation was also reported by Sohail et al. (2014), for the amylase of mango mealy bug where enzyme activity was found to increase from $1 \%$ to $3 \%$ starch substrate, after which further increase in substrate did not lead to increase in enzyme activity.

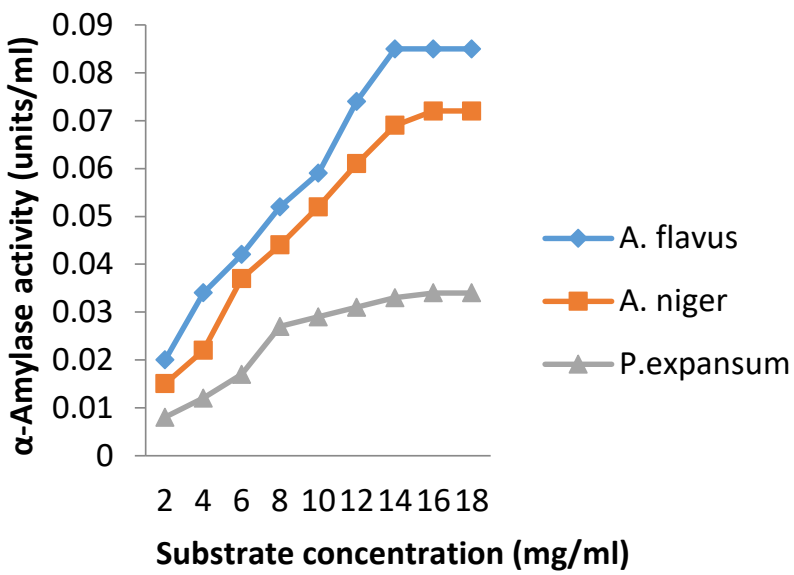

Fig. 4: Effect of substrate concentration on the activity of purified $\alpha$-amylase from cassava peels 
The effect of metal ions $\left(\mathrm{K}^{+}, \mathrm{Na}^{+}, \mathrm{Mg}^{2+}\right.$ and $\mathrm{Ca}^{2+}$ ) concentration on the activity of the aamylase are shown in Figures 5 to 8. The results show that increase in metal ions resulted to increase in enzyme activity. When potassium ion concentration was increased from $0 \mathrm{mg} / \mathrm{ml}$ to 30 $\mathrm{mg} / \mathrm{ml}$ there were increases in the a-amylase activity from $A$. flavus, $A$. niger and $P$. expansum respectively. Further increase in $\mathrm{K}^{+}$ concentration $(35 \mathrm{mg} / \mathrm{ml})$ did not lead to any increase in a-amylase activity of $A$. flavus and $A$. niger but lead to an increase in the a-amylase activity of $P$. expansum. However, the aamylase activity decreased when $40 \mathrm{mg} / \mathrm{ml}$ of $\mathrm{K}^{+}$was used in all ( $A$. flavus, $A$. niger and $P$. expansum). Similar trend was observed for $\mathrm{Mg}^{2+}$ and the result for both ions shows $A$. flavus $>A$. niger and $P$. expansum. Increase in the concentration of $\mathrm{Na}^{+}$and $\mathrm{Ca}^{2+}$ showed slight variation in pattern from those of $\mathrm{K}^{+}$and $\mathrm{Mg}^{2+}$. However, all the metal ions enhanced the activity of a-amylase irrespective of the source. The order was $\mathrm{Ca}^{2+}<\mathrm{Na}^{+}<\mathrm{Mg}^{2+}<\mathrm{K}^{+}$. These

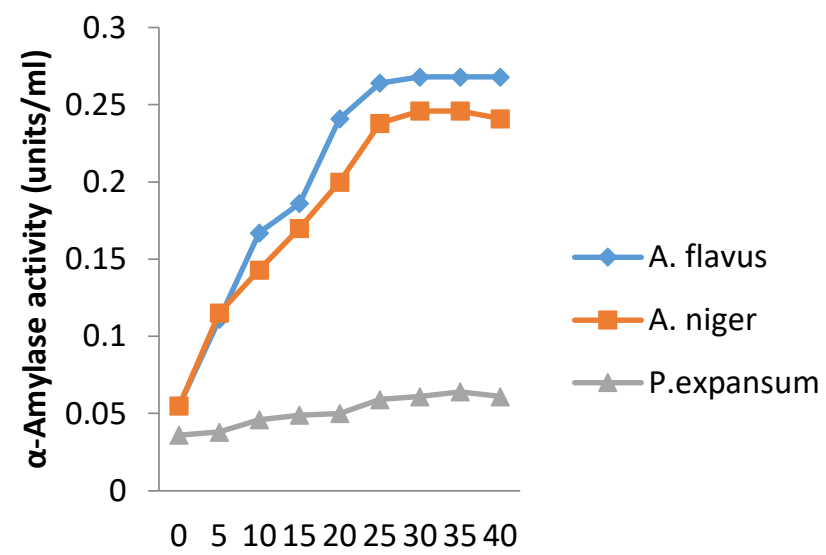

Potassium ion concentration $(\mathrm{mg} / \mathrm{ml})$

Fig. 5: Potassium ion $\left(\mathrm{K}^{+}\right)$on the

activity of purified $\alpha$-amylase from

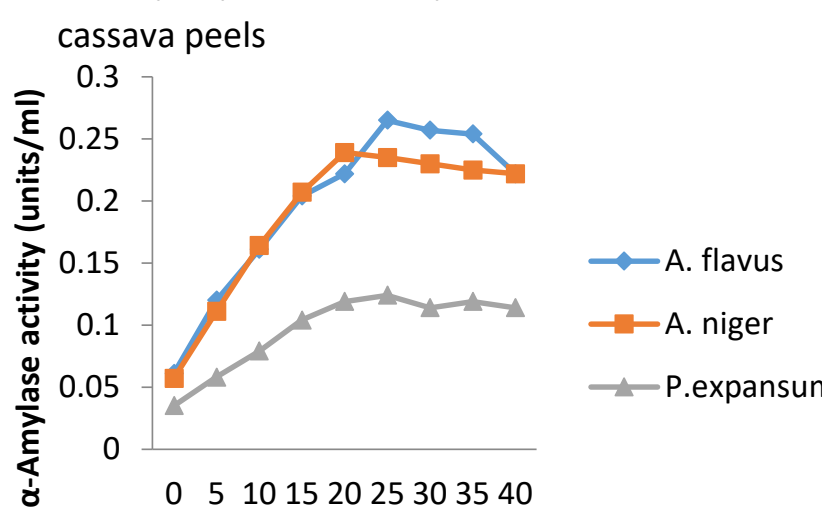

Magnesium ion concentration $(\mathrm{mg} / \mathrm{ml})$

Fig. 7: Effect of Magnesium ion ( $\mathrm{Mg}^{2+}$ ) on the 122 activity of purified a-amylase from cassava peels results agreed with those reported by Prakesh et al. (2011), where $\mathrm{K}^{+}$moderately increased the enzyme activity to a certain extent and then suppressed. Carvalho et al. (2008), reported that although $\mathrm{K}^{+}$did not stimulate the activity of a-amylase from Bacillus subtilis no significant inhibition of activity was observed. Saxena and Singh (2011), reported the enhancement of amylase activity in the presence of $\mathrm{Na}^{+}, \mathrm{Mg}^{2+}$ and $\mathrm{Ca}^{2+}$. Prakesh et al. (2011), reported that $\mathrm{Na}^{+}$had no detectable influence on the activity of amylase. Jha et al. (2013), considered $\mathrm{Mg}^{2+}$ to be the best metal ion for enhancing the genus Aspergillus, mycelia growth for amylase production, this was followed by $\mathrm{Ca}^{2+}$ according to them. Similarly, Sohail et al. (2014), reported the enhancement of amylase activity with $\mathrm{Ca}^{2+}$. All a-amylase bind at least on strongly conserved $\mathrm{Ca}^{2+}$ that is required for structural integrity, and for enzymatic activity (Aghajari et al., 2002), hence the ability of $\mathrm{Ca}^{2+}$ ion to enhance amylase activity.

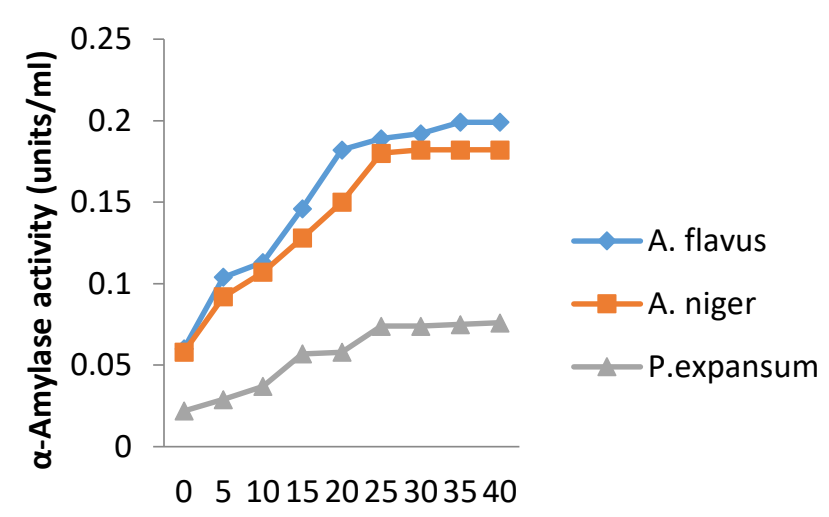

Sodium ion concentration $(\mathrm{mg} / \mathrm{ml})$

Fig.6: Sodium ion $\left(\mathrm{Na}^{+}\right)$on the activity of purified $\alpha$-amylase from cassava peels

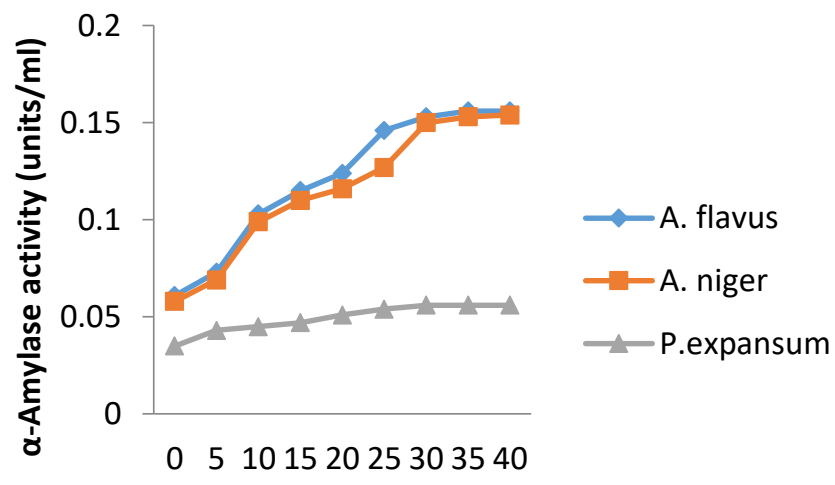

Calcium ion concentration $(\mathrm{mg} / \mathrm{ml})$

Fig. 8: Effect of Calcium ion $\left(\mathrm{Ca}^{2+}\right)$ on the activity of purified a-amylase from cassava peels 
The effect of heavy metal ions $\left(\mathrm{Hg}^{2+}\right.$ and $\left.\mathrm{Pb}^{2+}\right)$ concentration on the activity of a-amylase are shown in Figures $9-10$. The a-amylase activity from $P$. expansum drastically decreased from 0.033 units $/ \mathrm{ml}$ to 0.002 units $/ \mathrm{ml}$ as the $\mathrm{Hg}^{2+}$ concentration increase from $0 \mathrm{mg} / \mathrm{ml}$ to 4 $\mathrm{mg} / \mathrm{ml}$, further increase in $\mathrm{Hg}^{2+}$ concentration from $4 \mathrm{mg} / \mathrm{ml}$ to $10 \mathrm{mg} / \mathrm{ml}$ resulted in the loss of enzyme activity. Similar drastic decrease in activity was observed for the a-amylase from $A$. Flavus and $A$. niger, but the -amylase became deactivated when $8 \mathrm{mg} / \mathrm{ml}$ of $\mathrm{Hg}^{2+}$ concentration was applied. Lead ion $\left(\mathrm{Pb}^{2+}\right)$ was also found to

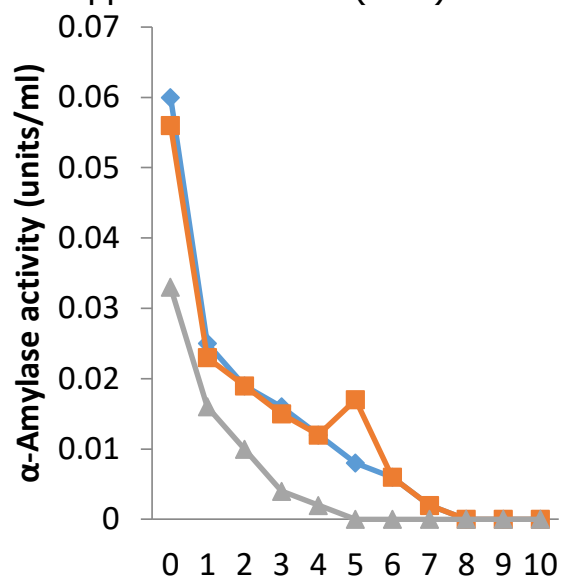

$\multimap$ A. flavus

12345678910

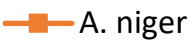

Mercury ion concentration $(\mathrm{mg} / \mathrm{ml})$

Fig. 9: Effect of Mercury ion $\left(\mathrm{Hg}^{2+}\right)$ on the activity of purified $\alpha$-amylase from cassava peels

Figure 11 shows the effect of EDTA on the activity of a-amylase. It was observed that the activity of a-amylase from $A$. flavus, $A$. niger and $P$. expansum were inhibited by all concentrations of EDTA used. This report also agrees with that of Fossi et al. (2011), where EDTA acted as an inhibitor to the a-amylase gradually decrease the activity of the a-amylase irrespective of the source. However, it was observed that increasing the concentration of the lead ion from $0 \mathrm{mg} / \mathrm{ml}$ to $10 \mathrm{mg} / \mathrm{ml}$ did not result in a-amylase deactivation but only resulted in decrease in activity. In general, the effect of heavy metals $\mathrm{CHg}^{2+}$ and $\left.\mathrm{Pb}^{2+}\right)$ on the activity of a-amylase was inhibitory at all concentrations (Figures 9 and 10). This report is in agreement with that of Sohail et al (2014) who reported the inhibition of amylase activity by $\mathrm{Pb}^{2+}$ and $\mathrm{Hg}^{2+}$.

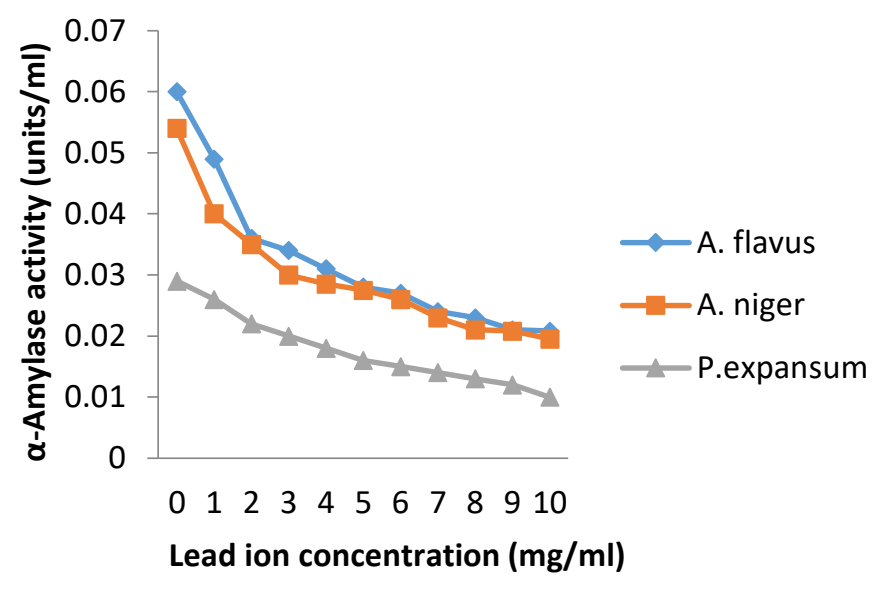

Fig. 10: Effect of Lead ion $\left(\mathrm{Pb}^{2+}\right)$ on the activity of purified $\alpha$-amylase from cassava peels

from Lactobacillus fermentum (04BBA19). Goyal et al. (2005) also reported that EDTA inhibited the activity of a-amylase from a Bacillus sp. Prakash et al. (2011) reported that EDTA had no detectable influence on the activity of a-amylase from soybean. 


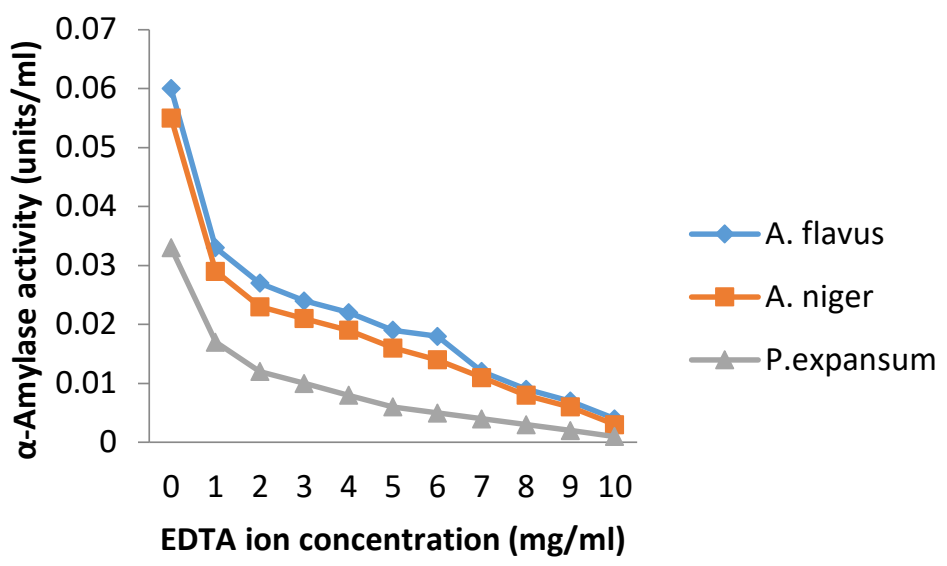

Fig. 11: Effect of EDTA on the activity of purified $\alpha$-amylase from cassava peels

\section{Conclusion}

Alpha-amylase, an important industrial enzyme can be produced by using cassava peels a biodegradable waste as substrate, thereby reducing its cost of production. The fungi ( $A$. flavus, $A$. niger and $P$. expansum) used in this study for the production of a-amylase were isolated from cassava peels undergoing biodegradation, this further proves that aamylase can be produced at a very low cost.

\section{Acknowledgment}

We wish to acknowledge Prof. F. A. Aisien of the Chemical Engineering Department, University of Benin for his immerse contributions towards the successful completion of this work.

\section{References}

Adeniran, A. H. and Abiose, S. H. (2009). Amylolytic potential of fungi isolated from some Nigerian Agricultural Wastes. African J. Biotech. 8(4): 667-672

Aghajari, N., Feller, G., Gerday, C. and Richard, H. (2002). Structural basis of a-amylase activation by chloride. Protein Sci. 11(6): 14351441.

Aisien, E.T. and Ikenebomeh, M. J. (2017). Enhancing the biodegradation process of Cassava (Manihot escculenta Crantz) Peels in dump site. Nig. J. Biotech. 33. $97-105$.

Bidderback, D. E. (1971). Amylases in developing barley seeds. Plant Physiol. 48:331334.
Barnett, H. L. and Hunter, B.B. (1972). Illustrated General of Imperfect fungi, $3^{\text {rd }}$ Ed. U.S.A. Burgress publication company, p. 241.

Biancarosa, I., Espe, M., Bruckner, C. G., Heesech, S., Liland, N., Waagbo, R., Torstensen, B., Lock, E. J. (2017). Amino acid composition, protein contents and nitrogen-to-protein conversion factors of 21 seaweed species from Norwegian waters. J. Appl. Phycol. 29:10011009.

Bole, S., Maji, A., Dey, A., Acharya, A. Dubey, S. and Rakeshlal (2013). Isolation, purification and characterization of amylase from airbornebacteria. World J. Pharm. Pharmaceutical Sc. 2(6):5878 - 5887.

Carvalho, R., Livia, T., Correa, R., Caroline, J. da Silva, M., Lelis, M. and Martins, L. (2008). Properties of an amylase from thermophilic Bacillus sp. Brazilian J. Microbio. 39(1): 102-107.

Couto, S. R. and Sanroman, M. A. (2006). 'Application of solid state fermentation to food industry-a review' J. Food. Eng. 76(3):291-302.

De Souza, P. M and eMagalhaes, D. O. P. (2010). Application of Microbial a-amylase in industry-A review. Brazilian J. Microbio. 41:850861.

Erdal, S. E. R. K. A. N. and Messu, T. (2010). 'Production of alpha-amylase by Penicillium expansum MT-1 in solid-state fermentation using waste loquat (Eriobotrya japonica Lindley) kernels as substrate' Romanian Biotechnological let. 15(3):5342-5350. 
Fossi, T. B., Tavea, F., Jiwoua, C. and Ndjouenkeu, R. (2011). Simultaneous production of raw starch degrading highly thermostable alpha amylase and lactic acid by Lactobacillus fermentum 04BBA19. Africa J. Biotech. 10(34): $6564-6574$.

Gilman, J. C. (2001). A manual of soil Fungi. $2^{\text {nd }}$ Indian Ed. Delhi. Biotech Books publication, p. 365.

Goyal, N., Gupta, J. K., Soni, S. K. (2005). A novel raw starch digesting thermostable aamylase from Bacillus sp. I-3 and its use in the direct hydrolysis of raw potato starch, Enzyme Microb. Technol. 37:723-734.

Gupta, R., Gigras, P. Mohapata, H., Goswami, V. K. and Chauhan, B. (2003). Microbial a-amylase: a biotechnological perspective. Process Biochem. $38: 1599-1616$.

Ikediugwu, F. E. O. and Ejale, A. U. (1980). Root-surface mycoflora of cassava (Manihot esculenta) and post-harvest rot of the tubers. Mycopathologia. 71(2):67-71.

International Livestock Research Institute News (2015). Processing African cassava peels, potentially a billion-dollar business. news.ilri.org https//news.ilri.org, 11/20/2015.

Jha, S., Rai, H., Chattopadhyay, R., Kaur, P.V. Indupriya, M. and Shanti, V. (2013). Effect of metal ions on amylase production. Recent Research in Sci. Tech. 5(2):52-53.

Kayode, O. (2016). Exploring the cassava industry's value chain opportunities for MSMEs. https://www:linkedin.com.pulse>explo.

Kunamneni, A., Permaul, K. and Singh, S. (2005). "Amylase production in solid state fermentation by the thermophilic fungus Thermomyces lanuginosus. J. Biosci. and Bioeng. 100(2): 168-171.

Lowry, O. H., Rosebrough, N. J. and Fair, A. L. (1951). Protein measurement with Folin-phenol reagent. J. Biol. Chem. 193:265-275.

Oboh, G. (2005). 'Isolation and characterization of amylase from fermented cassava (Manihot esculenta Crantz) waste water' African J. Biotech. 4(10):1117-1123.

Olutiola, P. O. and Ayre, P.G. (1973). Utilization of carbohydrate by Rhynchosporium secalis I. Growth sporulation on glucose, galactose and galacturonic acid. Physiol plant. 29:92-96.

Pitt, J. I. (1979). The Genus Penicillium and its telomorphic states Eupenicillium and Talanomyces. London Academic Press Inc. p. 634.

Prakash, O., Jaiswal, N. and Pandey, K. R. (2011). Effect of metal ions, EDTA and sulfhydryl reagents on soybean Amylase activity. Asian J. Biochem. 693): 282-290.

Prakasham, R. S., SubbaRao, C. H., Screenivas Rao, R. and Sarma, P.N. (2006). "Enhancement of acid amylase production by an isolated Aspergillus awamorl". J. Applied Microbio. 102(1): 204-211.

Rajunathan, R. and Padhmadas, R. (2013). Production Purification and Characterization of a-amylase using Streptomyces $s p$. PDS1 and Rhodococcussp. Isolated from Western Ghats. Int. J. Curr. Microbiol. App. Sci. 2(8): 206-214.

Saxena, R. and Rajni, S. (2011). Amylase Production by solid state fermentation of agroindustrial waste using Bascillus sp. Braz. J. Microbiol. 42(4): 1334-1342.

Sivaramakrishnan, S., Gangadharan, D., Nampoothiri, K. M., Soccol, C. R. and Pandey, A. (2006). 'a-Amylase from Mycrobial Sources - An Overview on Recent Developments '. Food Tech. Biotech. 44(22): 57-61.

Sodhi,H. K., Sharma, J. K., Gupta, J. K., Soni, S. K. (2005). Production of a thermostable aAmylase from Bacillus sp PS-7 by solid state fermentation and its synergistic use in the hydrolysis of malt starch for alcohol production. Process Biochem. 40: 525-534.

Sohail, M., Aqueel, A. M., Afzal, M. and Khall, S. M. (2014). Biochemical studies on the amylase of Mango mealybug (Drosicha stebbingi Green). Jurkish J. Entomol. 38(3): 
Sundarram, A. and Murthy, K. P. T. (2014). aAmylase production and applications: A review. J. App. And Environmental Microbiol. 2(4): 166175.

Tangphatsornruang, S., Naconsie, M., Thammarongtham, C. and Narangajavana, J. (2005). Isolation and characterization of an alpha-amylase gene in cassava (Manihot esculenta). Plant Physiol Biochem. 43:821-827.
Varalakshimi, K. N., Kumudini, B.S. Nandini, B. N., Solomon, J., Suhas, R., Mahesh, B. and Kavitha, A. P. (2009). Production and characterization of a-amylase from Aspergillus niger JG1 24 Isolated in Bangalore. Polish J. Microbio. 58(1): 29-26.

Whitcomb, D. C. and Lowe, M.E. (2007). Human pancreatic digestive enzymes. Dig. Dis. Sci. 52: 1- 17. 